\title{
Experimental Study on the Properties and Displacement Effects of Polymer Surfactant Solution
}

\author{
Ke-Liang Wang, Lei-Lei Zhang, Xue Li, and Yang-Yang Ming \\ The Key Lab of Enhanced Oil and Gas Recovery of the Ministry of Education, Northeast Petroleum University, Daqing 163318, China \\ Correspondence should be addressed to Ke-Liang Wang; wangk10608@126.com
}

Received 7 April 2013; Revised 29 September 2013; Accepted 14 October 2013

Academic Editor: Ibnelwaleed Ali Hussien

Copyright (c) 2013 Ke-Liang Wang et al. This is an open access article distributed under the Creative Commons Attribution License, which permits unrestricted use, distribution, and reproduction in any medium, provided the original work is properly cited.

\begin{abstract}
Based on the characteristics of oil reservoirs and the requirements of further enhancing oil recovery at high water cut stage of Pubei Oilfield, the displacement performance of polymer surfactant is evaluated. Reasonable injection parameters and oil displacement effects after water flooding are also researched. Compared with conventional polymer with intermediate molecular weight, polymer surfactant has the properties of higher viscosity at low concentration condition and lower interfacial tension. Laboratory experiments indicate that the displacement effect of polymer surfactant is much better than that of conventional polymer at a slug size of $0.57 \mathrm{PV}$. The oil recovery of polymer surfactant increases by more than $10 \%$ after water flooding. Considering the actual situation of low-permeability of Pubei Oilfield reservoirs, the system viscosity of $30 \mathrm{mPa} \cdot \mathrm{s}$ is chosen. The corresponding concentration of Type III polymer surfactant is $600 \mathrm{mg} / \mathrm{L}$ and the injected slug is $0.57 \mathrm{PV}$ and the oil recovery can be increased by $11.69 \%$.
\end{abstract}

\section{Introduction}

Polymer flooding has already entered the industrial application period in major reservoirs of Daqing Oilfield, and pilot trial has also been conducted in Pubei Oilfield, one of the many oilfields of Daqing Oilfield. Both laboratory and field data have shown that polymer flooding could improve oil recovery by nearly $10 \%$, but this value was not perfect [1]. It was indicated that the oil recovery of ASP flooding was 20\% higher than that of water flooding in Daqing Oilfield pilot tests $[2,3]$. However, some problems such as formation damage due to alkali scale, production well pollution, and effluent treatment difficulties appeared in ASP development process $[4,5]$. Experimental results showed that the oil recovery of binary combination flooding in major reservoirs increased by more than $15 \%$ [6]. However, the adsorption, diffusion, and migration properties of different chemical agents in porous media are quite different. This difference may result in the phenomenon of chromatographic separation and negative synergistic effect during the mixture system simultaneous flow [7]. In recent years, some functional groups have been grafted to hydrocarbon main chains to form a multivariate graft copolymer which is called functional polymer surfactant (also referred to as polymer surfactant) $[8,9]$. As a new type of polymer, polymer surfactant is a single component oil displacement agent. In addition to the general nature of polymer, polymer surfactant can improve solubilization and emulsification capacity of crude oil in the absence of alkali. At present, many main blocks in Daqing Oilfield have entered high water cut stage and the conventional polymer have already couldn't meet the requirements of tertiary oil recovery. Thus, the use of polymer surfactant is an attractive option in further enhancing oil recovery for high water cut or low-permeability oilfields.

The performance of Type I and Type III polymer surfactant produced by Shanghai Haibo Company was investigated in this paper. According to the reservoir characteristics of Pubei Oilfield, core flooding experiments were conducted to study the oil displacement effects. Besides, optimized system slug concentration and final oil recovery were achieved on the basis of experiment results. 
TABLE 1: The composition of fresh water and produced water.

\begin{tabular}{lcccccccc}
\hline Name & $\mathrm{PH}$ & $\begin{array}{c}\mathrm{Cl}^{-} \\
(\mathrm{mg} / \mathrm{L})\end{array}$ & $\begin{array}{c}\mathrm{SO}_{4}{ }^{2-} \\
(\mathrm{mg} / \mathrm{L})\end{array}$ & $\begin{array}{c}\mathrm{HCO}_{3}{ }^{-} \\
(\mathrm{mg} / \mathrm{L})\end{array}$ & $\begin{array}{c}\mathrm{CO}_{3}{ }^{2-} \\
(\mathrm{mg} / \mathrm{L})\end{array}$ & $\begin{array}{c}\mathrm{K}^{+}+\mathrm{Na}^{+} \\
(\mathrm{mg} / \mathrm{L})\end{array}$ & $\begin{array}{c}\mathrm{Ca}^{2+} \\
(\mathrm{mg} / \mathrm{L})\end{array}$ & $\begin{array}{c}\mathrm{Mg}^{2+} \\
(\mathrm{mg} / \mathrm{L})\end{array}$ \\
\hline $\begin{array}{l}\text { Fresh } \\
\text { water }\end{array}$ & 8.5 & 53.77 & 33.71 & 137.62 & 110.86 & 196.00 & 4.37 & 5.30 \\
$\begin{array}{l}\text { Produced } \\
\text { water }\end{array}$ & 7.8 & 877.00 & 10.47 & 694.53 & 862.07 & 1481.29 & 6.55 & 3.97 \\
\hline
\end{tabular}<smiles>[Y]NC(=O)C(CC(CC)C(N)=O)CC(CC(CC)C(N)=O)C(=O)O[X]</smiles>

FIGURE 1: Molecular structure of polymer surfactant.

\section{Properties of Polymer Surfactant}

2.1. Molecular Structure. Figure 1 shows the diagram of polymer surfactant molecular structure, where $\mathrm{X}, \mathrm{Y}$ represents one of the following functional groups, respectively: -OR, $-\mathrm{NHR},-\mathrm{RSO}_{3} \mathrm{Na}$, quaternary ammonium surfactant unit, cationic Gemini unit, - $\mathrm{RSH}$, and so forth.

Polymer surfactant has superior properties to conventional polymer because of the various functional groups in the molecular structure. For instance, quaternary ammonium surfactant unit, as one of the groups, is a kind of viscoelastic surfactant that has been identified; it can reduce the technical disadvantages of lacking solubilization, emulsification, the ability of altering rock wettability, and reducing oil-water interfacial tension when polymer is used alone as oil displacement agent.

2.2. Property of Increasing Viscosity. The sweep efficiency and displacement effect can be improved as the viscosity of polymer solution increases. Therefore, the polymer surfactant solution viscosity is an important parameter which reflects the performance of polymer.

The viscosity of Type I (solid content of $88.5 \%$ ) and Type III polymer surfactant (solid content of 90.2\%) was estimated at $45^{\circ} \mathrm{C}$. The results were compared with that of the conventional intermediate-molecular-weight polymer (relative molecular mass of $1570 \times 10^{4}$, solid content of $89.3 \%$ ) produced by Daqing Refining and Chemical Company under the same conditions. Brookfield viscometer was used in this study. The viscosity was measured at $6 \mathrm{r} / \mathrm{min}$ rotor speed (7.34 $\mathrm{s}^{-1}$ shear rate).

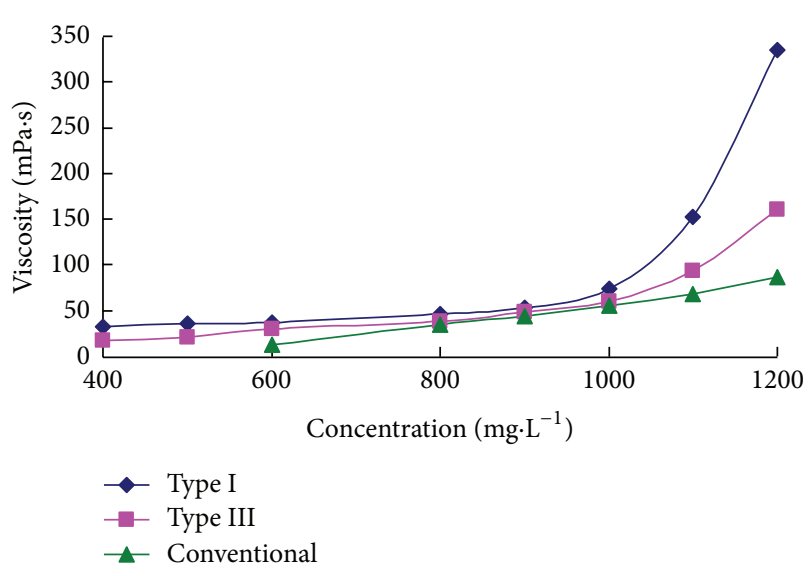

Figure 2: Viscosities versus concentrations of different polymer solutions prepared by fresh water.

Viscosity measurements were performed on the three polymer solutions with fresh water and produced water and the composition of the two waters is listed in Table 1.

Figures 2 and 3 show that both of Type I and Type III polymer surfactant solutions possess higher viscosity than conventional at the same concentration. As shown in Figure 2, there is a critical concentration in the range of $1000 \mathrm{mg} / \mathrm{L}-1100 \mathrm{mg} / \mathrm{L}$, and viscosity increasement is particularly evident when system concentration is above this critical concentration. The viscosity of Type I is better than that of Type III in Figure 2. Similarly, the critical concentration in produced water is lower and within the range of $600 \mathrm{mg} / \mathrm{L}-$ $800 \mathrm{mg} / \mathrm{L}$ in Figure 3, the viscosity of Type III is high and with great salt tolerance as well.

There is a self-crosslinking unit in Type I polymer surfactant, and the poor salt tolerance of this unit results in solution viscosity reduction as the salinity increases. While the quaternary ammonium surfactant unit in Type III polymer surfactant has great salt tolerance, thus, the solution viscosity is slightly influenced by water salinity. Therefore, the different salt tolerance leads to the different phenomena in fresh water and produced water.

2.3. Interfacial Tension. One mechanism of enhancing oil recovery for surfactant and polymer compound system is the ultralow interfacial tension produced by surfactant. Ultralow interfacial tension contributes to mobilizing trapped oil and displacing oil out of formation. Laboratory evaluation shows that polymer surfactant solution has a certain ability to reduce interfacial tension and exhibits some characteristics 
TABLE 2: Interfacial tensions ( $\mathrm{mN} / \mathrm{m})$ of Type I and Type III polymer surfactant prepared with fresh and produced water, respectively.

\begin{tabular}{lcccc}
\hline $\begin{array}{l}\text { Polymer concentration } \\
\left(\mathrm{mg} \cdot \mathrm{L}^{-1}\right)\end{array}$ & $\begin{array}{c}\text { Type I prepared by } \\
\text { fresh water }\end{array}$ & $\begin{array}{c}\text { Type I prepared by } \\
\text { produced water }\end{array}$ & $\begin{array}{c}\text { Type III prepared by } \\
\text { fresh water }\end{array}$ & $\begin{array}{c}\text { Type III prepared by } \\
\text { produced water }\end{array}$ \\
\hline 200 & 30.82 & 29.12 & 22.15 & 20.26 \\
400 & 31.21 & 28.69 & 23.14 & 22.32 \\
600 & 29.23 & 28.63 & 21.85 & 20.36 \\
800 & 29.01 & 28.12 & 22.18 & 21.26 \\
1000 & 29.51 & 27.65 & 22.75 & 19.85 \\
\hline
\end{tabular}

TABLE 3: Wetting angles of the cores treated before and after by Type I polymer surfactant.

\begin{tabular}{lcc}
\hline Core number & Wetting angles before $\left(^{\circ}\right)$ & Wetting angles after $\left(^{\circ}\right)$ \\
\hline Berea 200-1 & 99 & 95 \\
Berea 200-2 & 96 & 93 \\
Natural 200-1 & 120 & 123 \\
Natural 200-2 & 126 & 118 \\
\hline
\end{tabular}

TABLE 4: Wetting angles of the cores treated before and after by Type III polymer surfactant.

\begin{tabular}{lcc}
\hline Core number & Wetting angles before $\left(^{\circ}\right)$ & Wetting angles after $\left(^{\circ}\right)$ \\
\hline Berea 200-3 & 93 & 73 \\
Berea 200-4 & 96 & 87 \\
Natural 200-3 & 125 & 105 \\
Natural 200-4 & 130 & 102 \\
\hline
\end{tabular}

of surfactant. This property is due to the special structure of polymer surfactant. The hydrophilic and hydrophobic parts in the molecular structure have orientation on interface or surface and hence cause interfacial tension reduction. Experiment results are listed in Table 2. It is obvious that the interfacial tension of polymer surfactant solutions prepared by produced water is slightly lower than fresh water, and the ability of reducing interfacial tension of Type III is a little better than Type I. In addition, the interfacial tension of Type III is less than $24 \mathrm{mN} / \mathrm{m}$ either by fresh water or produced water.

2.4. Ability to Change Rock Wettability. In the process of water injection, oil phase and water phase coexist within the pores of rock. Whether the water attaches to the pore surface and displaces the oil or only squeezes out the oil in central pore mainly depends on the wettability of rock. Generally speaking, oil displacement efficiency of oil-wet reservoir is lower, while the water-wet reservoir is higher. Therefore, a suitable displacing agent is required to reduce the adhesion power of crude oil on the rock surface and hence improve oil displacement efficiency.

In this paper, Germany Dataphysics OCA20 video optical contact angle measuring device is used to evaluate the influence on the wettability of solid surface through measuring wetting angles. Type I and Type III polymer surfactant solutions and columnar natural cores and Berea cores are also used. Experimental procedure consists of the following

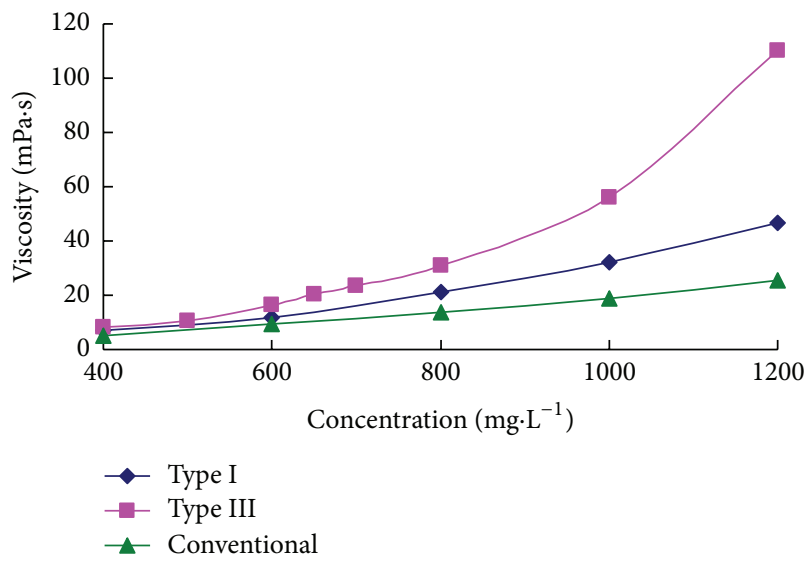

FIGURE 3: Viscosities versus concentrations of different polymer solutions prepared by produced water.

sequence: (1) make the $10 \mathrm{~cm}$ length columnar core sample into three sections, each section is a new short core with a length of $3 \mathrm{~cm}$; (2) the short cores were vacuumed for several hours and then saturated with formation water. Put the three short cores into core holders and saturate with crude oil; (3) after water flooding, take one of the short cores out of core holder. Dry the core and determine its wettability; (4) displace the other two cores, respectively, with 10 PV Type I and 10 PV Type III polymer surfactant solutions, dry the cores after sufficient follow-up water flooding, and then determine the wettability again. The results are listed in Tables 3 and 4 .

It is shown that the wetting angles of both kinds of cores changed significantly after treatment with Type III solution, and the wettability exhibits a tendency to water-wet. In contrast, the variation in wetting angles is not obvious after treatment with Type I solution, and the wettability is basically unchanged. Overall, Type III polymer surfactant solution has a certain ability to change rock wettability, it is because that the special surfactant unit in molecular structure is easily adsorbed onto the rock surface which result in hydrophobic ability weakened and hydrophilic ability enhanced.

\section{Core Flooding Experiments}

The oil displacement effect of Type I and Type III polymer surfactant solutions in different injection concentrations is concerned. Polymer surfactant solutions of different viscosity $30 \mathrm{mPa} \cdot \mathrm{s}, 40 \mathrm{mPa} \cdot \mathrm{s}$, and $60 \mathrm{mPa} \cdot \mathrm{s}$ are prepared, respectively. 
TABLE 5: Experimental results of Type I polymer surfactant flooding.

\begin{tabular}{|c|c|c|c|c|c|c|}
\hline Experimental project & $\begin{array}{l}\text { Absolute permeability } \\
\left(10^{-3} \mu \mathrm{m}^{2}\right)\end{array}$ & $\begin{array}{l}\text { Porosity } \\
(\%)\end{array}$ & $\begin{array}{c}\text { Oil saturation } \\
(\%)\end{array}$ & $\begin{array}{l}\text { Water flooding } \\
\text { recovery (\%) }\end{array}$ & $\begin{array}{l}\text { Polymer flooding } \\
\text { recovery (\%) }\end{array}$ & $\begin{array}{c}\text { Overall } \\
\text { recovery }(\%)\end{array}$ \\
\hline $\begin{array}{l}\text { Polymer surfactant }(400 \mathrm{mg} / \mathrm{L} \text {, } \\
31.83 \mathrm{mPa} \cdot \mathrm{s})+ \text { water flooding }\end{array}$ & 309 & 23.83 & 73.16 & 37.60 & 10.38 & 47.98 \\
\hline $\begin{array}{l}\text { Polymer surfactant }(650 \mathrm{mg} / \mathrm{L} \text {, } \\
39.7 \mathrm{mPa} \cdot \mathrm{s})+ \text { water flooding }\end{array}$ & 298 & 24.09 & 72.36 & 37.50 & 13.48 & 50.98 \\
\hline $\begin{array}{l}\text { Polymer surfactant }(925 \mathrm{mg} / \mathrm{L} \text {, } \\
61.35 \mathrm{mPa} \cdot \mathrm{s})+ \text { water flooding }\end{array}$ & 307 & 24.90 & 69.88 & 37.88 & 16.29 & 54.17 \\
\hline
\end{tabular}

TABLE 6: Experimental results of Type III polymer surfactant flooding.

\begin{tabular}{|c|c|c|c|c|c|c|}
\hline Experimental project & $\begin{array}{l}\text { Absolute permeability } \\
\qquad\left(10^{-3} \mu \mathrm{m}^{2}\right)\end{array}$ & $\begin{array}{l}\text { Porosity } \\
(\%)\end{array}$ & $\begin{array}{l}\text { Oil saturation } \\
(\%)\end{array}$ & $\begin{array}{l}\text { Water flooding } \\
\text { recovery }(\%)\end{array}$ & $\begin{array}{l}\text { Polymer flooding } \\
\text { recovery }(\%)\end{array}$ & $\begin{array}{c}\text { Overall } \\
\text { recovery }(\%)\end{array}$ \\
\hline $\begin{array}{l}\text { Polymer surfactant }(600 \mathrm{mg} / \mathrm{L} \text {, } \\
30.5 \mathrm{mPa} \cdot \mathrm{s})+ \text { water flooding }\end{array}$ & 336 & 24.78 & 72.43 & 39.49 & 11.69 & 51.18 \\
\hline $\begin{array}{l}\text { Polymer surfactant }(850 \mathrm{mg} / \mathrm{L} \text {, } \\
40.2 \mathrm{mPa} \cdot \mathrm{s})+ \text { water flooding }\end{array}$ & 310 & 24.33 & 72.51 & 40.12 & 16.30 & 56.42 \\
\hline $\begin{array}{l}\text { Polymer surfactant }(1000 \mathrm{mg} / \mathrm{L} \text {, } \\
60.53 \mathrm{mPa} \cdot \mathrm{s})+ \text { water flooding }\end{array}$ & 321 & 24.91 & 69.83 & 39.47 & 18.21 & 57.68 \\
\hline
\end{tabular}

The experiments were carried out to research the influence of polymer surfactant viscosity on oil displacement efficiency when slug size is $0.57 \mathrm{PV}$ and the optimal injection concentration is also determined.

3.1. Experimental Materials. Cores: the artificial heterogeneous core is selected, the core size is $4.5 \mathrm{~cm} \times 4.5 \mathrm{~cm} \times 30 \mathrm{~cm}$, and the Dykstra-Persons permeability variation factor is 0.68 . The core sample includes three layers with the same thickness and different permeability. The permeability of three layers is $100 \times 10^{-3} \mu \mathrm{m}^{2}, 220 \times 10^{-3} \mu \mathrm{m}^{2}$, and $580 \times 10^{-3} \mu \mathrm{m}^{2}$, respectively, and the average permeability is about $300 \times$ $10^{-3} \mu \mathrm{m}^{2}$; water: fresh water and produced water from no. 7 Oil Plant of Daqing Oilfield; oil: simulated oil which is prepared with dehydrated crude oil and kerosene, the viscosity is $5.1 \mathrm{mPa} \cdot \mathrm{s}$ at $45^{\circ} \mathrm{C}$; solutions: according to the requirement of viscosity, polymer solutions of different concentrations with fresh water are prepared, including Type I solutions of $400 \mathrm{mg} / \mathrm{L}, 650 \mathrm{mg} / \mathrm{L}$, and $925 \mathrm{mg} / \mathrm{L}$, Type III solutions of $600 \mathrm{mg} / \mathrm{L}, 850 \mathrm{mg} / \mathrm{L}$, and $1000 \mathrm{mg} / \mathrm{L}$, and conventional polymer solutions of $785 \mathrm{mg} / \mathrm{L}$.

3.2. Experimental Procedure. The core was first vacuumed for several hours at ambient temperature and then the core was $100 \%$ saturated with formation water and pore volume was determined. After the first step, the core was saturated with simulated oil to establish irreducible water and the residual water saturation and initial oil saturation were determined during this period. Water flooding was continued until $98 \%$ water cut (oilfield economic limit of water cut) and oil recovery was calculated at the end of water flooding. After water flooding, a predetermined volume of polymer solution was injected according to different projects. Then follow-up water flooding was contained until $98 \%$ water cut, and the additional oil recovery of polymer flooding was calculated.

\subsection{Results and Discussion}

3.3.1. Oil Displacement Efficiency. Type I and Type III polymer surfactant solutions of three viscosities $30 \mathrm{mPa} \cdot \mathrm{s}$, $40 \mathrm{mPa} \cdot \mathrm{s}$, and $60 \mathrm{mPa} \cdot \mathrm{s}$ were selected for coreflooding experiment. The oil displacement efficiency results were compared with that of the conventional polymer with a viscosity of $30 \mathrm{mPa} \cdot \mathrm{s}$. The injected polymer slug size is always maintained $0.57 \mathrm{PV}$ at each experiment. Experimental results are listed in Tables 5, 6, and 7 .

It is shown that both of the two polymer surfactant flooding can improve oil recovery by more than $10 \%$ after water flooding, and the oil displacement efficiency increases with the increase of solution concentration. At the same viscosity, the oil displacement efficiency of Type III polymer surfactant is better than that of Type I, and the efficiency of Type I and conventional polymer is almost the same.

It is indicated that the follow-up water flooding after polymer surfactant is significantly longer than conventional polymer, and corresponding water injection volume is larger (Figure 4). For example, the follow-up water flooding after Type III is the longest and this process needs about $1.17 \mathrm{PV}$ injection water. While Type I requires only about $0.78 \mathrm{PV}$ injection water, the difference is $0.39 \mathrm{PV}$. This is due to the ability of Type III polymer to change rock wettability and reduce interfacial tension. This ability leads to residual oil saturation further reducing and thus improves microscopic oil displacement efficiency.

3.3.2. Injection Pressure. As shown in Figure 4, polymer surfactant injection pressure is higher than conventional polymer in coreflooding experiment. At the same viscosity, the polymer surfactant thread molecule is larger than the conventional polymer and then results in the higher injection pressure. 
TABLE 7: Experimental results of conventional intermediate-molecular-weight polymer flooding.

\begin{tabular}{|c|c|c|c|c|c|c|}
\hline Experimental project & $\begin{array}{l}\text { Absolute permeability } \\
\left(10^{-3} \mu \mathrm{m}^{2}\right)\end{array}$ & $\begin{array}{l}\text { Porosity } \\
(\%)\end{array}$ & $\begin{array}{c}\text { Oil saturation } \\
(\%)\end{array}$ & $\begin{array}{l}\text { Water flooding } \\
\text { recovery }(\%)\end{array}$ & $\begin{array}{l}\text { Polymer flooding } \\
\text { recovery }(\%)\end{array}$ & $\begin{array}{l}\text { Overall } \\
\text { recovery }(\%)\end{array}$ \\
\hline $\begin{array}{l}\text { Polymer }(785 \mathrm{mg} / \mathrm{L}, 29.7 \mathrm{mPa} \cdot \mathrm{s})+ \\
\text { water flooding }\end{array}$ & 305 & 24.22 & 70.75 & 39.75 & 10.25 & 50.00 \\
\hline
\end{tabular}
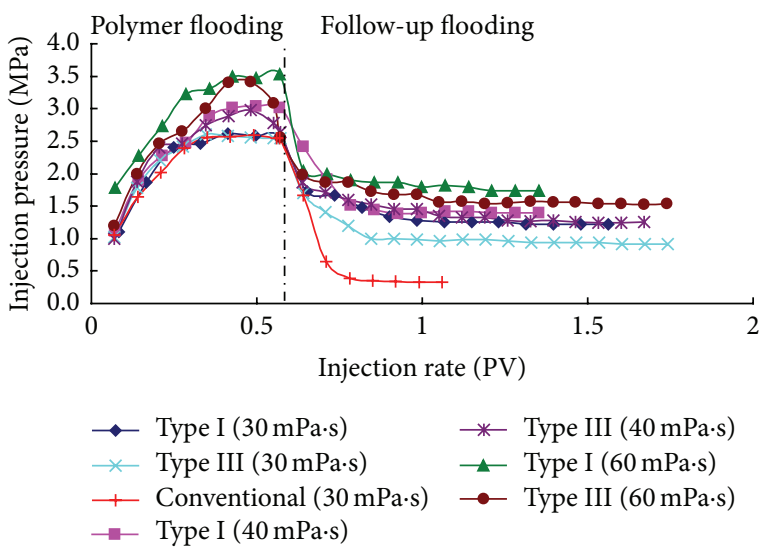

FIGURE 4: Injection rates versus pressures of different kinds of polymer.

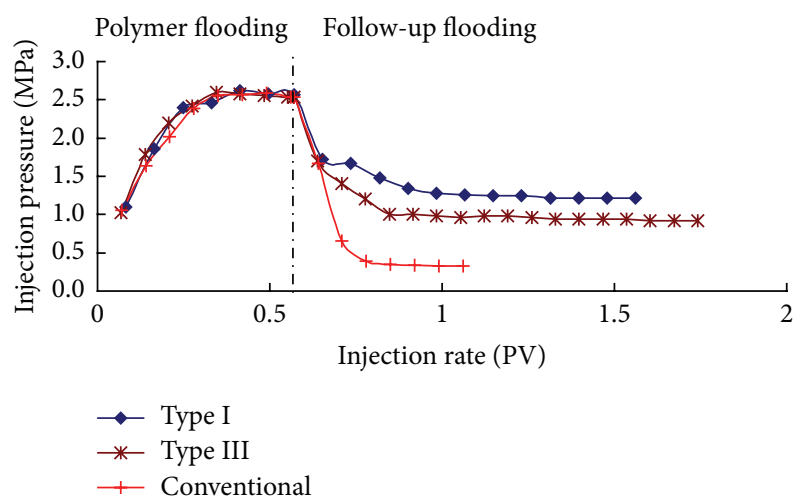

FIGURE 5: Injection rates versus pressures of different kinds of polymer at $30 \mathrm{mPa} \cdot \mathrm{s}$.

It can be seen that the injection pressure is relatively high for Type I and Type III polymer surfactant at $40 \mathrm{mPa} \cdot \mathrm{s}$ and $60 \mathrm{mPa} \cdot \mathrm{s}$ from Figures 4 and 5. High injection pressure may result in some injection problems when applied in low permeability oilfield. But both Type I and Type III polymer surfactant have a lower injection pressure at $30 \mathrm{mPa} \cdot \mathrm{s}$. In follow-up water flooding, the strong adsorption of polymer surfactant can maintain high injection pressure and obtain larger swept volume so that oil recovery can be improved. In addition, polymer surfactant can reach or even exceed the conventional polymer displacement efficiency at a lower concentration under the same conditions. Overall, it is suggested that Type III polymer surfactant solution of $30 \mathrm{mPa} \cdot \mathrm{s}$ is the most reasonable choice as injection agent.

\section{Conclusions}

(1) The property of increasing viscosity of polymer surfactant is better than that of conventional polymer. In fresh water, the property of Type I is better than Type III. However, the situation is just the reverse in produced water.

(2) Compared with the conventional intermediatemolecular-weight polymer produced by Daqing Refining and Chemical Company, polymer surfactants possess a certain ability to reduce the interfacial tension and change the wettability of rock.

(3) Oil displacement efficiency increases with the increase of solution viscosity. At the same viscosity, the oil displacement efficiency of Type III polymer surfactant is better than that of Type I, and the efficiency of Type I and conventional polymer is almost the same.

(4) Type III polymer surfactant has great injection capacity when viscosity is $30 \mathrm{mPa} \cdot \mathrm{s}$, which is suited for the application in Pubei low-permeability reservoirs. So, Type III polymer surfactant solution prepared with fresh water is recommended.

\section{References}

[1] M. F. Fakoya and S. N. Shah, "Rheological properties of surfactant-based and polymeric nano-fluids," in SPE/ICoTA Coiled Tubing \& Well Intervention Conference \& Exhibition, The Woodlands, Tex, USA, 2013, SPE 163921.

[2] L. Eoff, D. Dalrymple, and B. R. Reddy, "Development of associative polymer technology for acid diversion in sandstone and carbonate lithology," SPE Production \& Facilities, vol. 20, no. 3, pp. 250-256, 2005.

[3] X. Guo, A. A. Abdala, B. L. May, S. F. Lincoln, S. A. Khan, and R. K. Prud'homme, "Rheology control by modulating hydrophobic and inclusion associations in modified poly(acrylic acid) solutions," Polymer, vol. 47, no. 9, pp. 2976-2983, 2006.

[4] S. Barhoum and A. Yethiraj, "An NMR study of macromolecular aggregation in a model polymer-surfactant solution," The Journal of Chemical Physics, vol. 132, no. 2, Article ID 024909, 2010.

[5] K. Holmberg, B. Jonsson, and B. Kronberg, Surfactats and Polymers in Aqueous Solution, Wiley, New York, NY, USA, 2003.

[6] S. Wu, R. A. Shanks, and G. Bryant, "Properties of hydrophobically modified polyacrylamide with low molecular weight and interaction with surfactant in aqueous solution," Journal of Applied Polymer Science, vol. 100, no. 6, pp. 4348-4360, 2006.

[7] Q. Niuyabin et al., "Research on hydrophobically associating water-soluble polymer used for EOR," in SPE International Symposium on Oilfield Chemistry, Houston, Tex, USA, 2001, SPE 65378. 
[8] J. Lu, P. J. Liyanage, S. Solairaj et al., "Recent technology developments in chemical enhanced oil recovery," in International Petroleum Technology Conference (IPTC '13), March 2013, IPTC 16425.

[9] M. Roshanfekr, R. T. Johns, G. Pope et al., "Effect of pressure, temperature, and solution gas on oil recovery from surfactant polymer floods," in SPE Annual Technical Conference and Exhibition (ATCE '09), pp. 4398-4412, October 2009, SPE 125095. 

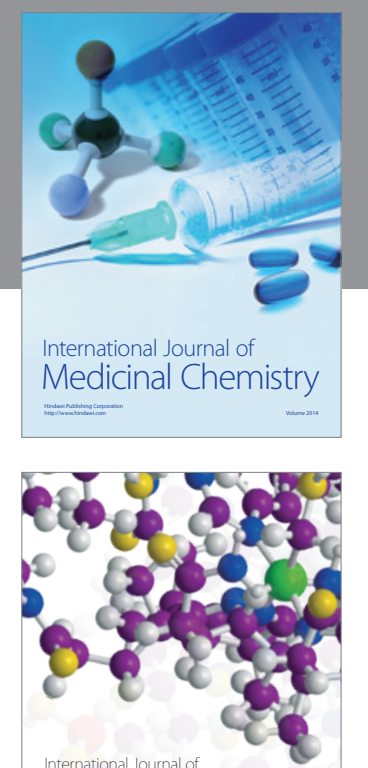

\section{Carbohydrate} Chemistry

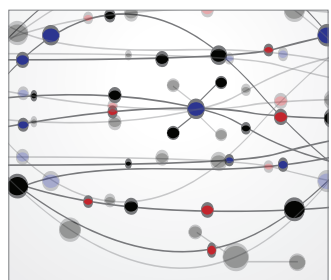

The Scientific World Journal
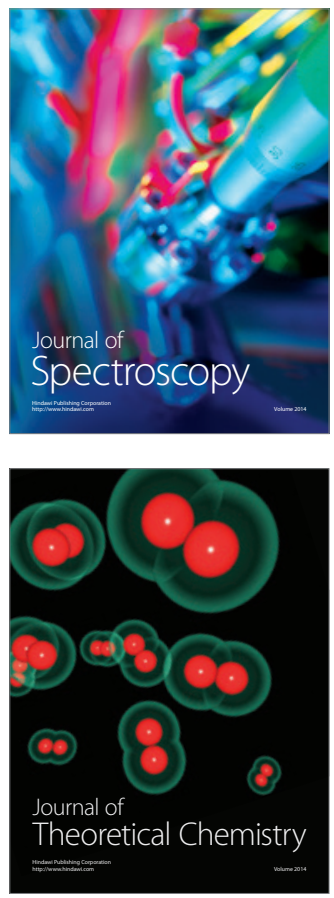
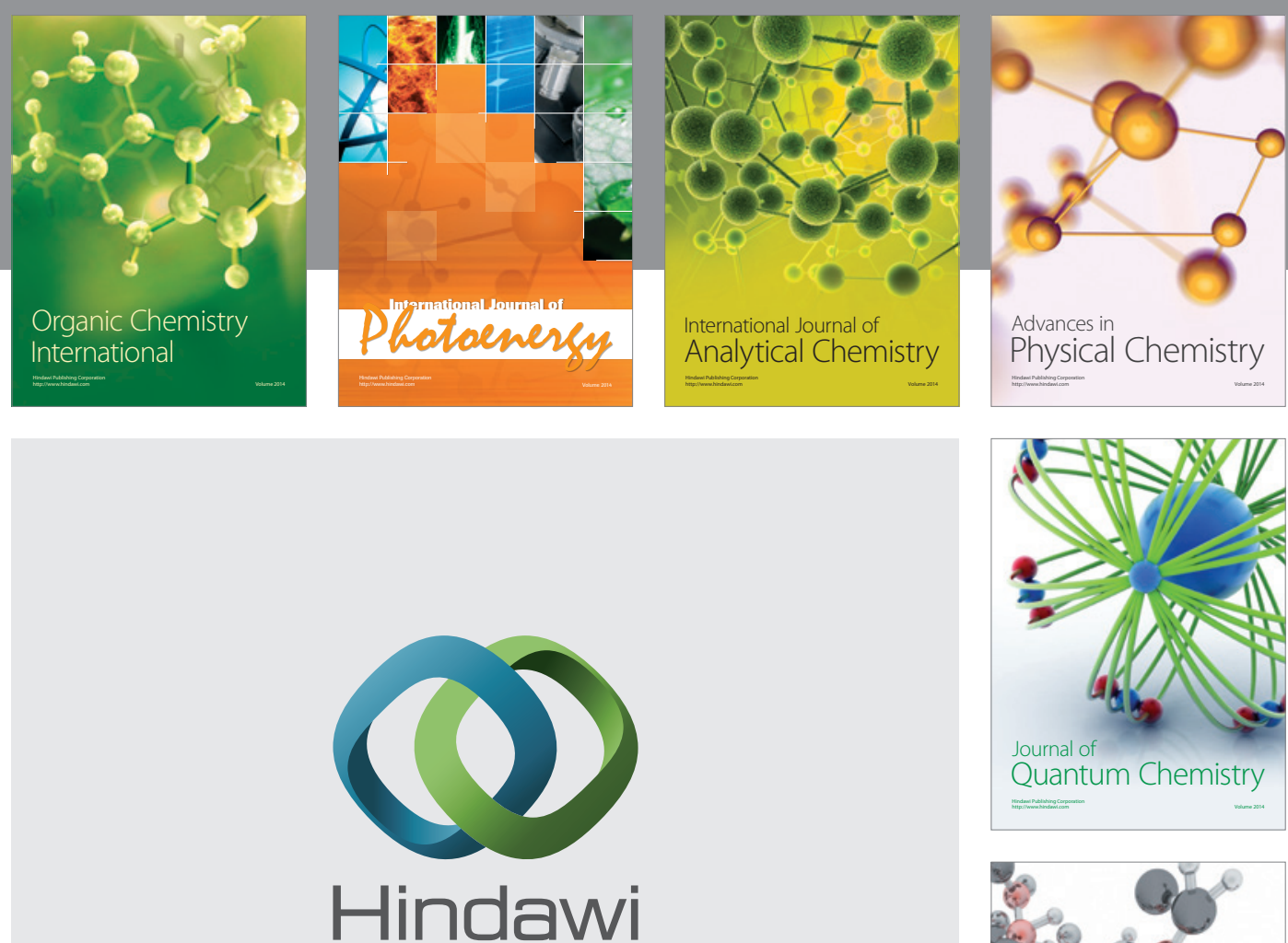

Submit your manuscripts at

http://www.hindawi.com

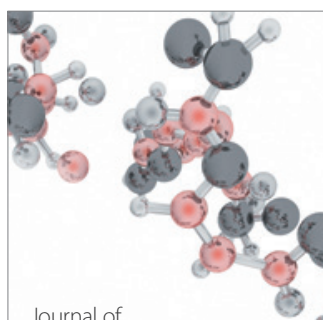

Analytical Methods

in Chemistry

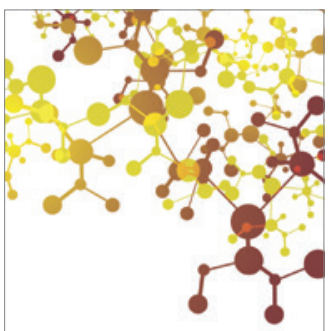

Journal of

Applied Chemistry

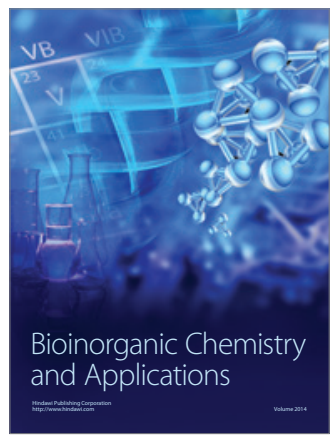

Inorganic Chemistry
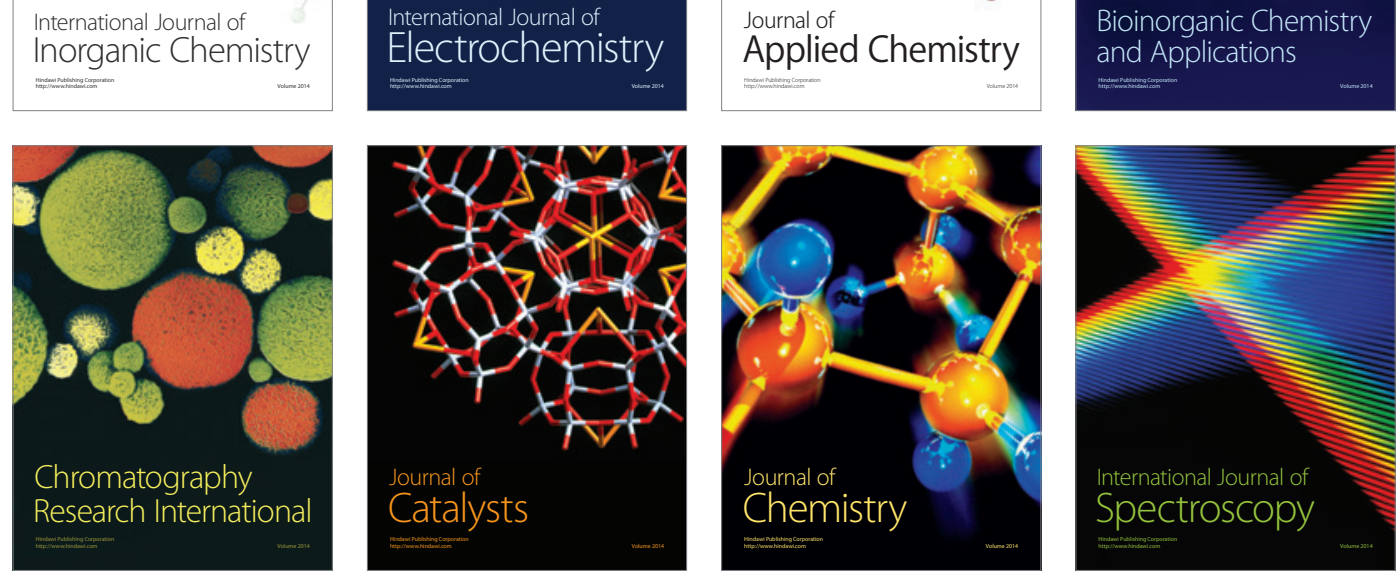